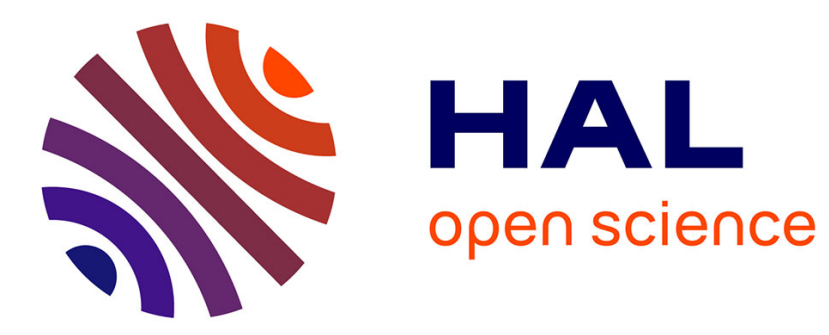

\title{
Comparison of milk samples collected from some buffalo breeds and crossbreeds in China
}

\author{
Qi Sun, Jia-Ping Lv, Lu Liu, Shu-Wen Zhang, Xiao Liang, Jing Lu
}

\section{To cite this version:}

Qi Sun, Jia-Ping Lv, Lu Liu, Shu-Wen Zhang, Xiao Liang, et al.. Comparison of milk samples collected from some buffalo breeds and crossbreeds in China. Dairy Science \& Technology, 2014, 94 (4), pp.387-395. 10.1007/s13594-013-0159-9 . hal-01234861

\section{HAL Id: hal-01234861 \\ https://hal.science/hal-01234861}

Submitted on 27 Nov 2015

HAL is a multi-disciplinary open access archive for the deposit and dissemination of scientific research documents, whether they are published or not. The documents may come from teaching and research institutions in France or abroad, or from public or private research centers.
L'archive ouverte pluridisciplinaire HAL, est destinée au dépôt et à la diffusion de documents scientifiques de niveau recherche, publiés ou non, émanant des établissements d'enseignement et de recherche français ou étrangers, des laboratoires publics ou privés. 


\title{
Comparison of milk samples collected from some buffalo breeds and crossbreeds in China
}

\author{
Qi Sun • Jia-ping Lv • Lu Liu • Shu-wen Zhang • \\ Xiao Liang • Jing Lu
}

Received: 20 November 2013 / Revised: 28 December 2013 / Accepted: 30 December 2013 /

Published online: 4 April 2014

(C) INRA and Springer-Verlag France 2014

\begin{abstract}
Buffaloes are the second largest milk producers in the world and China has rich buffalo resources. However, the nutrient potential of buffalo milk (BM) has not been fully determined and the information about BM from different breeds and crossbreeds is still quite limited. Therefore, the gross composition, fatty acids, and amino acids of BM were determined in milk samples from Murrah and Nili-Ravi river breeds and first $\left(\mathrm{F}_{1}\right)$ and second $\left(\mathrm{F}_{2}\right)$ generation of Murrah $\times$ Guangxi swamp buffalo crossbreeds. Buffalo breeds consist of two pure river breeds (Murrah and Nili-Ravi) and two crossbreeds (Murrah river buffalo $\times$ Guangxi swamp buffalo, first and second generation) $\left(\mathrm{F}_{1}\right.$ and $\left.\mathrm{F}_{2}\right)$. Results revealed the $\mathrm{BM}$ contained $19.28 \%$ total solids, $5.30 \%$ crude protein, $7.97 \%$ fat on average, high levels of total amino acids, and essential amino acids. From the major minerals investigated, BM was also rich in total calcium and phosphorus contents (192.2 and $124.3 \mathrm{mg} 100 \mathrm{~mL}^{-1}$, respectively). Statistically significant differences $(P<0.05)$ in the proportions of gross chemical composition, fatty acids, and amino acids were observed between river buffalo breeds and river $\times$ swamp crossbreeds. Milk from crossbreed buffaloes was found to contain more monounsaturated fatty acids (MUFAs) and polyunsaturated fatty acids (PUFAs) and less saturated fatty acids (SFAs) than milk from Murrah and Nili-Ravi buffaloes. In addition, BM samples collected from crossbreeds were good supply of total amino acids and essential amino acids. The results indicate that BM is of significance in contributing to human nutrition and our data also suggest that BM from Chinese crossbreeds has better nutritional value than that of river buffalo breeds.
\end{abstract}

Keywords Buffalo $\cdot$ Milk $\cdot$ Chemical composition $\cdot$ Fatty acids $\cdot$ Amino acids

Q. Sun · J.P. Lv $(\bowtie) \cdot$ L. Liu $\cdot$ S.W. Zhang $\cdot$ X. Liang $\cdot$ J. Lu

Key Laboratory of Agro-food Processing of Ministry of Agriculture, Institute of Agro-Products

Processing Science and Technology, Chinese Academy of Agricultural Sciences, P. O. Box 5109, No.2

Yuanmingyuan West Road, Haidian District, Beijing 100193, People's Republic of China

e-mail: caasdairy@gmail.com 


\section{Introduction}

As the second largest milk-producing animal in the world, buffaloes are widely distributed throughout Asia. In 2004, China ranked third in the world in terms of buffalo herds and buffalo milk (BM) production, only after India and Pakistan (FAO 2004). As described in a previously published review (El-Salam and El-Shibiny 2011), $\mathrm{BM}$ is characterized by high levels of almost all the nutrients. Unfortunately, Asian buffalo, with great promise for production, has not been well promoted. The Food and Agricultural Organization (FAO 2000) has rightly defined buffalo as important but "an asset undervalued." Of the two buffalo types, river buffalo and swamp buffalo in China, the former is a superior buffalo breed for milk production and the latter is traditionally regarded mainly as an excellent breed for draft, but a poor milk producer (Han et al. 2007). Nevertheless, swamp buffalo is found to have even higher fat, protein, lactose, and ash than river buffalo (Thac 1979). Guangxi Autonomous Region, which is situated in southern China, has the largest buffalo populations in China. To improve the yield of BM and strengthen the dairy production, the local government in Guangxi Autonomous Region imported Murrah and Nili-Ravi buffalo from India and Pakistan, respectively, in the 1960s and 1970s. Animal breeding scientists strived to gain fertile crossbreed offspring by crossbreeding the native swamp buffalo breeds with excellent river buffalo breeds. Considering the nutritional value and economic potential of BM, it is necessary to determine and study the composition and nutrient profiles of BM samples in China. However, data from China at breed level for buffalo are rare and little attention has been focused on the chemical compositions of BM.

The purpose of the present study is, therefore, to analyze the compositional properties of milk samples from buffalo breeds and crossbreeds in Guangxi Autonomous Region of China. The gross chemical composition, fatty acids, and amino acids of BM were examined in the study. The results will be useful in future studies dealing with buffalo breeding and dairy processing.

\section{Materials and methods}

\subsection{Collection of BM samples}

Fresh raw BM samples were obtained at a large-scale buffalo ranch in October 2011 from Nanning City in the Guangxi Autonomous Region of China. Sampling was carried out twice a day at 6:30 a.m. and 4:30 p.m. The morning and afternoon samples were then mixed before analysis was conducted. A total of 72 samples of BM were collected from individual buffaloes of Murrah and Nili-Ravi river breeds and first $\left(\mathrm{F}_{1}\right)$ and second $\left(\mathrm{F}_{2}\right)$ generation of Murrah $\times$ Guangxi swamp buffalo crossbreeds (18 samples each). These included 18 samples each from 2 breeds of Murrah and NiliRavi pure river buffalo and 2 crossbreeds (Murrah river buffalo $\times$ Guangxi swamp buffalo) first and second generation ( $F_{1}$ and $F_{2}, 18$ samples each). We collected approximately $300 \mathrm{~mL}$ BM samples from individual buffaloes for each buffalo breed and all BM samples were kept in plastic sterilized flasks after milking. A total of 0.3 g.L - $^{-1}$ of thimerosal (Sigma-Aldrich, St. Louis, USA) was added as a preservative. 


\subsection{Determination of gross chemical composition}

Total solids were determined gravimetrically after the milk was dried in a forcedconvection oven at $105^{\circ} \mathrm{C}$ until a constant weight was achieved (Zhang et al. 2005). Total nitrogen content in milk was determined by the Kjeldahl method. A nitrogen conversion factor of 6.38 was used to calculate protein contents of milk samples. Milk fat content was determined by the Gerber method (AOAC 2000) and lactose content was determined by using a lactoscope (Delta instruments, Laboratoire Humeau, France).

\subsection{Determination of calcium and phosphorus}

The concentrations of total calcium in $\mathrm{BM}$ samples were determined by atomic absorption spectrophotometer (AA-6300, Shimadzu, Japan). The contents of total phosphorus in BM were determined by phosphomolybdenum blue spectrophotometric method (Taguchi et al. 1985). Before analysis, all milk samples were pretreated by microwave digestion method as described by Qi Sun et al. (Sun et al. 2012).

\subsection{Determination of fatty acid composition}

Milk fat extraction was carried out according to the official method of ISO-IDF (2001). The fat extract was stored at $-20^{\circ} \mathrm{C}$ before fatty acid analysis. Fatty acid methyl esters were prepared according to ISO-IDF $(2002 \mathrm{a}$, b) and were analyzed by gas chromatography (Varian GC system $450+$ with a flame-ionization detector) using a CP-Sil 88 capillary column $(100 \mathrm{~m} \times 0.25 \mathrm{~mm}$ i.d. with $0.2-\mu \mathrm{m}$ film thickness; Varian Inc., USA).

The column parameters were as follows: initial column temperature was held at $80{ }^{\circ} \mathrm{C}$ for $1 \mathrm{~min}$ after auto injection, temperature-programmed at $2{ }^{\circ} \mathrm{C} \cdot \mathrm{min}^{-1}$ to $200{ }^{\circ} \mathrm{C}$ and held there for $2 \mathrm{~min}$, and finally temperature-programmed at $5^{\circ} \mathrm{C} \cdot \mathrm{min}^{-1}$ to $210^{\circ} \mathrm{C}$ and held there for $11 \mathrm{~min}$. High purity nitrogen $(99 \%)$ was the carrier gas at a flow rate of $1 \mathrm{~mL} \cdot \mathrm{min}^{-1}$ and the inlet temperature was $280{ }^{\circ} \mathrm{C}$. Identification of each individual fatty acid was confirmed by comparison with the retention times of the pure methyl ester standards (NuChek Prep, Elysian, MN). Peak area and percentage of individual fatty acids were quantified according to the ISO-IDF (2002a, b) method and fatty acid results were expressed as grams per $100 \mathrm{~g}^{-1}$ milk fat content.

\subsection{Determination of amino acid profiles}

The contents of amino acid in buffalo milk samples were determined according to the Chinese standard method GB/T 5009.124-2003(2003). The starting weight of BM for sample preparation was $1.5 \mathrm{~g}$ (accurate to $0.1 \mathrm{mg}$ ). Subsequently, BM samples were thoroughly mixed and hydrolyzed using $10 \mathrm{~mL}$ of 6 mol.L $\mathrm{L}^{-1}$ hydrochloric acid in sealed glass ampullae for $24 \mathrm{~h}$ at $110^{\circ} \mathrm{C}$ under nitrogen atmosphere. The hydrolyzate was centrifuged and the supernatant was then set up to a volume of $25 \mathrm{~mL}$ with ultrapure water. Then $1-\mathrm{mL}$ diluent was set to $5 \mathrm{~mL}$ with $0.02 \mathrm{~mol} . \mathrm{L}^{-1}$ hydrochloric acid for amino acid analysis after filtering through a $0.22-\mu \mathrm{m}$ syringe filter. The analysis of amino acid was achieved by amino acid analyzer (L-8900, Hitachi, Japan). 


\subsection{Statistical analysis}

The data obtained were statistically analyzed by a general liner model procedure of the Fisher's least significant difference test using SAS software, version 9.0 (SAS Institute Inc., USA). This test combines one-way analysis of variance with comparison of differences between the mean values of the treatments at the significance level of $P<0.05$.

\section{Results and discussions}

\subsection{Milk chemical compositions of buffalo breeds and crossbreeds}

The average values of the gross chemical compositions (total solids, crude protein, fat, lactose, calcium, and phosphorus) of milk from buffalo breeds and crossbreeds are presented in Table 1.

The lactose contents in the milk from buffalo breeds and crossbreeds were similar but their other chemical components differed. The contents of total solids, crude protein, fat, and total calcium of buffalo crossbreeds were significantly higher $(P<0.05)$ than that of river buffalo breeds, in agreement with the Han et al. (2007) who determined the contents of total solids, crude protein, fat and ash in river BM were lower than those of crossbreeds. No statistically significant differences $(P>0.05)$ were observed for milk chemical compositions between crossbreeds $F_{1}$ and $F_{2}$. It is also evident that BM from Murrah buffalo contained significantly lower amounts $(P<0.05)$ of total solids, fat, and total phosphorus compared with the other BM samples. In our study, average lactation yields for pure river buffalo breeds, Murrah and Nili-Ravi, are 1,900 and $1,970 \mathrm{~L}$ in our study, respectively. However, the local swamp buffalo produces less milk than pure river buffalo and average lactation yield is around $700 \mathrm{~L}$ for Guangxi swamp buffalo. By crossbreeding pure river buffalo with local swamp buffalo, the milk production performance of hybrids can be greatly improved. For example, in this study, average lactation yields for buffalo crossbreeds, $\mathrm{F}_{1}$ and $\mathrm{F}_{2}$, are 1,490 and $1,800 \mathrm{~L}$, respectively. It is well known that there is a negative correlation

Table 1 Milk chemical composition (mean $\pm \mathrm{SD}, n=18$ ) of buffalo breeds and crossbreeds

\begin{tabular}{|c|c|c|c|c|c|}
\hline & M & $\mathrm{N}$ & $\mathrm{F}_{1}$ & $\mathrm{~F}_{2}$ & Average \\
\hline Protein $(\% w / w)$ & $4.75 \pm 0.36^{\mathrm{a}}$ & $5.14 \pm 0.73^{\mathrm{a}}$ & $5.78 \pm 1.14^{\mathrm{b}}$ & $5.51 \pm 0.46^{\mathrm{b}}$ & $5.30 \pm 0.45$ \\
\hline Fat $(\% w / w)$ & $6.86 \pm 1.28^{\mathrm{a}}$ & $7.99 \pm 1.57^{\mathrm{b}}$ & $8.35 \pm 1.72^{b c}$ & $8.69 \pm 1.86^{\mathrm{c}}$ & $7.97 \pm 0.79$ \\
\hline Lactose $(\% w / w)$ & $4.60 \pm 0.52$ & $4.74 \pm 0.81$ & $4.59 \pm 0.87$ & $4.45 \pm 1.00$ & $4.60 \pm 0.12$ \\
\hline Total solids $(\% w / w)$ & $17.07 \pm 1.22^{\mathrm{a}}$ & $19.80 \pm 3.05^{\mathrm{b}}$ & $20.05 \pm 1.84^{\mathrm{b}}$ & $20.22 \pm 2.54^{\mathrm{b}}$ & $19.28 \pm 1.40$ \\
\hline Calcium (mg.100 mL ${ }^{-1}$ ) & $194.1 \pm 5.31^{\mathrm{ab}}$ & $180.7 \pm 4.94^{\mathrm{a}}$ & $196.0 \pm 9.33^{\mathrm{b}}$ & $198.2 \pm 8.09^{\mathrm{b}}$ & $192.2 \pm 7.88$ \\
\hline Phosphorus (mg.100 mL $\mathrm{mL}^{-1}$ ) & $116.8 \pm 3.68^{\mathrm{a}}$ & $133.0 \pm 2.01^{\mathrm{b}}$ & $126.4 \pm 3.20^{\mathrm{bc}}$ & $121.2 \pm 1.49^{\mathrm{c}}$ & $124.3 \pm 6.97$ \\
\hline
\end{tabular}

$M$ (Murrah) and $N$ (Nili-Ravi)-pure river buffalo; $\mathrm{F}_{1}, \mathrm{~F}_{2}$-crossbreed buffalo (Murrah river buffalo $\times$ Guangxi swamp buffalo) first and second generation. Different letters in a row indicate significant differences according to LSD test $(P<0.05)$ 
between milk yield and milk composition. This could explain why buffalo crossbreeds contained higher levels of chemical components than pure river buffalo.

\subsection{Milk fatty acid composition of buffalo breeds and crossbreeds}

Little information is available on the fatty acid composition of milk samples from buffalo breeds and crossbreeds in China. In the present study, milk fatty acids (FAs) from two pure river buffalo breeds of Murrah and Nili-Ravi, and two buffalo crossbreeds of river buffalo $\times$ swamp buffalo, including $\mathrm{F}_{1}$ and $\mathrm{F}_{2}$, are presented in Table 2 . The major FAs in all BM samples were myristic acid (C14:0), palmitic acid (C16:0), stearic acid (C18:0), and oleic acid (C18:1), which together accounted for roughly $74.61 \%$ of total FAs. The saturated fatty acids (SFAs) accounted for $76.11 \%$ and the

Table 2 Contents (mean $\pm \mathrm{SD}, n=18$ ) of milk fatty acids ( $100 \mathrm{~g}^{-1}$ fat) from buffalo breeds and crossbreeds

\begin{tabular}{|c|c|c|c|c|c|}
\hline \multirow[t]{2}{*}{ Fatty acid } & \multicolumn{4}{|l|}{ Milk of } & \multirow[t]{2}{*}{ Average } \\
\hline & $\mathrm{M}$ & $\mathrm{N}$ & $\mathrm{F}_{1}$ & $\mathrm{~F}_{2}$ & \\
\hline $\mathrm{C} 4: 0$ & $6.09 \pm 0.29^{\mathrm{a}}$ & $7.47 \pm 0.48^{\mathrm{b}}$ & $7.11 \pm 0.43^{\mathrm{b}}$ & $6.45 \pm 0.34^{\mathrm{ab}}$ & $6.78 \pm 0.62$ \\
\hline $\mathrm{C} 6: 0$ & $3.13 \pm 0.27^{\mathrm{a}}$ & $2.41 \pm 0.17^{\mathrm{b}}$ & $2.49 \pm 0.17^{\mathrm{b}}$ & $2.85 \pm 0.17^{\mathrm{ab}}$ & $2.72 \pm 0.33$ \\
\hline C8:0 & $1.25 \pm 0.10$ & $1.30 \pm 0.09$ & $1.18 \pm 0.11$ & $1.25 \pm 0.13$ & $1.24 \pm 0.05$ \\
\hline $\mathrm{C} 10: 0$ & $2.43 \pm 0.24$ & $2.63 \pm 0.24$ & $2.27 \pm 0.20$ & $2.47 \pm 0.29$ & $2.45 \pm 0.15$ \\
\hline $\mathrm{C} 12: 0$ & $2.95 \pm 0.26$ & $3.17 \pm 0.26$ & $2.71 \pm 0.21$ & $2.85 \pm 0.30$ & $2.92 \pm 0.19$ \\
\hline C14:0 & $11.67 \pm 0.61^{\mathrm{a}}$ & $12.01 \pm 0.41^{\mathrm{a}}$ & $10.24 \pm 0.66^{\mathrm{b}}$ & $11.04 \pm 0.95^{\mathrm{b}}$ & $11.24 \pm 0.78$ \\
\hline c9-C14:1 & $0.76 \pm 0.08$ & $0.98 \pm 0.08$ & $0.85 \pm 0.22$ & $0.73 \pm 0.13$ & $0.83 \pm 0.11$ \\
\hline $\mathrm{C} 16: 0$ & $34.35 \pm 0.99^{\mathrm{a}}$ & $33.86 \pm 0.45^{\mathrm{a}}$ & $29.11 \pm 0.79^{b}$ & $31.97 \pm 0.99^{b}$ & $32.32 \pm 2.37$ \\
\hline c9-C16:1 & $2.03 \pm 0.22$ & $2.38 \pm 0.32$ & $1.80 \pm 0.37$ & $1.94 \pm 0.27$ & $2.04 \pm 0.25$ \\
\hline $\mathrm{C} 17: 0$ & $0.36 \pm 0.02^{\mathrm{a}}$ & $0.34 \pm 0.01^{\mathrm{a}}$ & $0.44 \pm 0.03^{\mathrm{b}}$ & $0.40 \pm 0.04^{\mathrm{ab}}$ & $0.39 \pm 0.04$ \\
\hline C18:0 & $9.77 \pm 0.89$ & $8.71 \pm 0.26$ & $11.71 \pm 1.46$ & $10.90 \pm 1.01$ & $10.27 \pm 1.31$ \\
\hline t6-C18:1 & $0.22 \pm 0.01$ & $0.21 \pm 0.02$ & $0.34 \pm 0.05$ & $0.27 \pm 0.03$ & $0.26 \pm 0.06$ \\
\hline t9-C18:1 & $0.08 \pm 0.01$ & $0.06 \pm 0.00$ & $0.09 \pm 0.01$ & $0.07 \pm 0.01$ & $0.08 \pm 0.01$ \\
\hline $\mathrm{t} 11-\mathrm{C} 18: 1$ & $2.36 \pm 0.22$ & $1.89 \pm 0.06$ & $2.59 \pm 0.35$ & $2.21 \pm 0.24$ & $2.26 \pm 0.29$ \\
\hline c9-C18:1 & $14.02 \pm 1.02^{\mathrm{a}}$ & $14.22 \pm 0.73^{\mathrm{a}}$ & $16.61 \pm 0.86^{\mathrm{b}}$ & $16.54 \pm 1.77^{\mathrm{b}}$ & $15.35 \pm 1.42$ \\
\hline c9,c12-C18:2 & $0.42 \pm 0.03^{\mathrm{a}}$ & $0.44 \pm 0.01^{\mathrm{a}}$ & $0.53 \pm 0.05^{\mathrm{b}}$ & $0.44 \pm 0.02^{\mathrm{a}}$ & $0.46 \pm 0.05$ \\
\hline c9,t11-C18:2 & $0.69 \pm 0.07$ & $0.63 \pm 0.04$ & $0.74 \pm 0.09$ & $0.60 \pm 0.06$ & $0.67 \pm 0.06$ \\
\hline c9,c12,c15-C18:3 & $0.11 \pm 0.01$ & $0.09 \pm 0.00$ & $0.13 \pm 0.02$ & $0.10 \pm 0.01$ & $0.11 \pm 0.02$ \\
\hline $\mathrm{C} 20: 0$ & $0.19 \pm 0.02$ & $0.18 \pm 0.01$ & $0.21 \pm 0.02$ & $0.19 \pm 0.02$ & $0.19 \pm 0.01$ \\
\hline SFAs & $72.23 \pm 1.67^{\mathrm{a}}$ & $72.13 \pm 1.20^{\mathrm{a}}$ & $67.53 \pm 1.43^{b}$ & $70.41 \pm 1.68^{\mathrm{b}}$ & $70.58 \pm 2.19$ \\
\hline MUFAs & $19.50 \pm 1.28^{\mathrm{a}}$ & $19.79 \pm 1.08^{\mathrm{a}}$ & $22.30 \pm 1.00^{\mathrm{b}}$ & $21.80 \pm 1.64^{\mathrm{b}}$ & $20.85 \pm 1.41$ \\
\hline PUFAs & $1.31 \pm 0.10^{\mathrm{a}}$ & $1.24 \pm 0.05^{\mathrm{a}}$ & $1.49 \pm 0.11^{\mathrm{b}}$ & $1.20 \pm 0.08^{\mathrm{a}}$ & $1.31 \pm 0.13$ \\
\hline
\end{tabular}

$M$ (Murrah) and $N$ (Nili-Ravi)-pure river buffalo; $\mathrm{F}_{1}, \mathrm{~F}_{2}$-crossbreed buffalo (Murrah river buffalo $\times$ Guangxi swamp buffalo) first and second generation

SFAs sum of all saturated fatty acids, MUFAs sum of all monounsaturated fatty acids, PUFAs sum of all polyunsaturated fatty acids

Different letters in a row indicate significant differences according to LSD Test $(P<0.05)$ 
percentage of unsaturated fatty acids (UFAs) constituted $23.89 \%$ of total FAs in BM were mostly monounsaturated fatty acids (MUFAs), constituting $22.48 \%$ of total FAs. Similar results of the FA groups in milk fat have been reported in Indian buffalo breeds by Ramamurthy et al. (Ramamurthy and Narayanan 1971) and in Pakistani buffalo breeds by Talpur et al. (Talpur et al. 2007).

Table 2 also shows the contents of individual FAs in milk samples from different buffalo breeds and crossbreeds. The results indicated that a few individual milk FAs between buffalo breeds and crossbreeds had a statistically different content $(P<0.05)$ and no significant variation $(P>0.05)$ was observed for the content of most of the individual FAs. The total SFAs, MUFAs, and PUFAs of milk samples from buffalo breeds and crossbreeds were determined, respectively. The significant variation $(P<0.05)$ was observed between buffalo breeds and crossbreeds when the total of SFAs, MUFAs, and PUFAs were considered. In particular, milk from buffalo crossbreeds contained more MUFAs and PUFAs and less SFAs than pure river buffalo breeds. There is convincing evidence that diets with high amounts of MUFAs and PUFAs will reduce low-density lipoprotein cholesterol and the replacement of SFAs with UFAs reduces risk for coronary artery disease (Kris-Etherton et al. 1999; Mensink et al. 2003). From a nutritional viewpoint, milk samples from buffalo crossbreeds seem to have a better FA profile.

Table 3 Contents (mean $\pm \mathrm{SD}, n=18$ ) of milk amino acids (g.100 $\mathrm{g}^{-1}$ protein) from buffalo breeds and crossbreeds

\begin{tabular}{|c|c|c|c|c|c|}
\hline & M & $\mathrm{N}$ & $\mathrm{F}_{1}$ & $\mathrm{~F}_{2}$ & Average \\
\hline Thr & $3.37 \pm 0.17^{\mathrm{a}}$ & $3.66 \pm 0.19^{\mathrm{ab}}$ & $3.96 \pm 0.18^{\mathrm{b}}$ & $3.77 \pm 0.52^{\mathrm{b}}$ & $3.69 \pm 0.25$ \\
\hline Val & $4.59 \pm 0.20^{\mathrm{a}}$ & $4.98 \pm 0.22^{\mathrm{b}}$ & $5.47 \pm 0.15^{\mathrm{b}}$ & $4.95 \pm 0.59^{\mathrm{b}}$ & $5.01 \pm 0.36$ \\
\hline Met & $2.15 \pm 0.11$ & $2.30 \pm 0.13$ & $2.54 \pm 0.12$ & $2.29 \pm 0.28$ & $2.32 \pm 0.16$ \\
\hline Ile & $4.08 \pm 0.18^{\mathrm{a}}$ & $4.28 \pm 0.21^{\mathrm{a}}$ & $4.74 \pm 0.19^{b}$ & $4.36 \pm 0.55^{\mathrm{ab}}$ & $4.37 \pm 0.28$ \\
\hline Leu & $3.52 \pm 0.33$ & $3.72 \pm 0.58$ & $3.82 \pm 0.92$ & $3.74 \pm 0.77$ & $3.70 \pm 0.13$ \\
\hline Phe & $3.66 \pm 0.12^{\mathrm{a}}$ & $4.24 \pm 0.29^{\mathrm{ab}}$ & $5.03 \pm 0.26^{\mathrm{b}}$ & $4.70 \pm 0.91^{\mathrm{b}}$ & $4.41 \pm 0.59$ \\
\hline Lys & $5.73 \pm 0.21$ & $5.78 \pm 0.14$ & $5.91 \pm 0.04$ & $5.95 \pm 0.57$ & $5.84 \pm 0.11$ \\
\hline His & $1.83 \pm 0.19^{\mathrm{a}}$ & $2.02 \pm 0.11^{\mathrm{a}}$ & $2.21 \pm 0.09^{\mathrm{b}}$ & $2.01 \pm 0.28^{\mathrm{a}}$ & $2.03 \pm 0.16$ \\
\hline Asp & $5.71 \pm 0.17^{\mathrm{a}}$ & $6.17 \pm 0.22^{\mathrm{ab}}$ & $6.52 \pm 0.19^{b}$ & $6.28 \pm 0.77^{\mathrm{b}}$ & $6.17 \pm 0.34$ \\
\hline Ser & $3.98 \pm 0.18^{\mathrm{a}}$ & $4.34 \pm 0.21^{\mathrm{ab}}$ & $4.72 \pm 0.17^{\mathrm{b}}$ & $4.37 \pm 0.52^{\mathrm{ab}}$ & $4.35 \pm 0.30$ \\
\hline Glu & $18.53 \pm 0.57^{\mathrm{a}}$ & $20.18 \pm 0.79^{\mathrm{ab}}$ & $22.06 \pm 0.53^{b}$ & $20.07 \pm 0.38^{\mathrm{ab}}$ & $20.21 \pm 1.45$ \\
\hline Gly & $1.45 \pm 0.09$ & $1.58 \pm 0.14$ & $1.75 \pm 0.11$ & $1.58 \pm 0.27$ & $1.59 \pm 0.12$ \\
\hline Ala & $2.40 \pm 0.10$ & $2.65 \pm 0.16$ & $2.84 \pm 0.18$ & $2.67 \pm 0.39$ & $2.64 \pm 0.18$ \\
\hline Cys & $1.35 \pm 0.09$ & $1.25 \pm 0.07$ & $1.14 \pm 0.05$ & $1.22 \pm 0.08$ & $1.24 \pm 0.09$ \\
\hline Tyr & $3.92 \pm 0.16$ & $4.34 \pm 0.22$ & $4.12 \pm 0.51$ & $4.28 \pm 0.49$ & $4.16 \pm 0.19$ \\
\hline Arg & $2.06 \pm 0.02$ & $2.26 \pm 0.09$ & $2.32 \pm 0.08$ & $2.30 \pm 0.31$ & $2.24 \pm 0.12$ \\
\hline Pro & $8.29 \pm 0.24^{\mathrm{a}}$ & $8.66 \pm 0.42^{\mathrm{ab}}$ & $8.69 \pm 0.31^{\mathrm{b}}$ & $8.84 \pm 0.79^{b}$ & $8.62 \pm 0.23$ \\
\hline
\end{tabular}

$M$ (Murrah) and $N$ (Nili-Ravi)-pure river buffalo; $\mathrm{F}_{1}, \mathrm{~F}_{2}$-crossbreed buffalo (Murrah river buffalo $\times$ Guangxi swamp buffalo) first and second generation

Different letters in a row indicate significant differences according to LSD Test $(P<0.05)$ 
In the SFAs category, with three predominant SFAs (C14:0, C16:0, C18:0), only the content of stearic acid (C18:0) was not significantly different $(P>0.05)$ between buffalo breeds and crossbreeds. Compared with river buffalo Murrah and Nili-Ravi, crossbreed buffalo $F_{1}$ and $F_{2}$ contained lower contents of myristic acid (C14:0) and palmitic acid (C16:0) which appears to be favorable for human health because of their negative role in atherosclerosis. The same result also existed in the yak crossbreeds (He et al. 2011). In the UFAs class, the content of the predominant MUFA oleic acid (C18:1) was significantly higher $(P<0.05)$ in crossbreed $\mathrm{F}_{1}$ and $\mathrm{F}_{2}$ than in pure river BM. Trans-11 C18:1 (vaccenic acid) was the predominant trans C18:1 in all BM samples. However, trans double bounds in position 4 to 12 were also observed in low concentrations in $\mathrm{BM}$ fat. Crossbreed buffalo $\mathrm{F}_{1}$ and $\mathrm{F}_{2}$ were richer in trans-11 C18:1 and cis-9, trans-11 CLA than pure river buffalo breeds, having an average vaccenic acid value of $2.40 \mathrm{~g} .100 \mathrm{~g}^{-1}$ fat and an average value for cis-9, trans-11 CLA of $0.67 \mathrm{~g} .100 \mathrm{~g}^{-1}$ fat. The results obtained also supported the evidence of the presence of a positive correlation between trans-11 C18:1 and cis-9, trans-11 CLA (Goudjil et al. 2004).

\subsection{Milk amino acid composition of buffalo breeds and crossbreeds}

The high-quality protein in milk plays a crucial role in nutrition which could provide amino acid (AA) for the human body, especially in developing countries where diets are largely cereal based. Data on AA at breed level for buffalo are very rare; we found only one study in a recent review (Medhammar et al. 2012) and there have been no previous reports on the difference in AA contents of buffalo at breed level in China.

The content of each AA, expressed as gram of amino acid per $100 \mathrm{~g}$ protein, is shown in Table 3. It is clear that all BM samples were a rich source of indispensable amino acids. In all BM samples, the predominant AA is glutamic acid, followed by proline and aspartic acid. Similar results have also been found in Holstein cow and yak milk (Guo et al. 2007; Sheng et al. 2008). These studies suggested that bovine milk is a good supply of glutamic acid that could be used in the biological protein metabolism in the body. The AA content of BM could be affected by breeds and milk yield. The mean values of individual AA in Murrah BM were similar to that of Nili-Ravi BM except for valine. Meanwhile, the data suggested that crossbreeds contained higher levels of AA than river buffalo breeds for the majority of amino acids. Obviously, the percentages of essential AA in the protein of buffalo crossbreed were higher than those of pure river buffalo Murrah and Nili-Ravi. The results in the study were similar to previously reported data (Zeng et al. 2007). As a rich source of amino acids, BM is worthy of further studies.

\section{Conclusions}

Compared with river buffalo breeds, BM from crossbreeds had higher levels of nutrition components, including total solids, fat, protein, total calcium, and AA profile. Crossbreed buffalo $F_{1}$ and $F_{2}$ contained more calculated amounts of MUFAs and PUFAs and less SFAs than Murrah and Nili-Ravi buffalo. The contents of trans-11 C18:1 and cis-9, trans-11 CLA were significantly different $(P<0.05)$ between river 
buffalo breeds and crossbreeds. The development and utilization of BM have gradually gained more attention in China. However, it is necessary to carry out more studies on the physicochemical properties of BM in order to develop the biodiversity database.

Acknowledgment This work was supported by the National Science \& Technology Program during the Twelfth Five-year Plan Period (no.2012BAD29B03, no.2013BAD18B10) and the National Natural Science Foundation of China (no.31371808, no.31301521). The authors thank Guangxi Buffalo Research Institute, Chinese Academy of Agricultural Science for facilitating us with BM sample collections. We also thank Dr. Hankie Uluko and Dr. Lauren for proof-reading and improving the manuscript's English.

\section{References}

AOAC (2000) AOAC Official Method: Fat Content of Raw and Pasteurized Whole Milk Gerber Method by Weight Official (Method I). Association of Official Analytical Chemists, Washington, USA

Chinese standard method GB/T 5009.124-2003 (2003). Method for determination of amino acids in foods. Beijing, China: China National Standard

El-Salam MHA, El-Shibiny S (2011) A comprehensive review on the composition and properties of buffalo milk. Dairy Sci Technol 91(6):663-699

Goudjil H, Fontecha J, Luna P, de la Fuente MA, Alonso L, Juárez M (2004) Quantitative characterization of unsaturated and trans fatty acids in ewe's milk fat. Lait 84(5):473-482

Guo H, Pang K, Zhang X, Zhao L, Chen S, Dong M, Ren F (2007) Composition, physiochemical properties, nitrogen fraction distribution, and amino acid profile of donkey milk. J Dairy Sci 90(4):1635-1643

FAO (2004) Available from http://faostat.fao.org/faostat/collections?subset=agriculture

FAO (2000) Water Buffalo: an Asset Undervalued, pp. 1-6. FAO Regional Office for Asia and the Pacific, Bangkok, Thailand

Han B-Z, Meng Y, Li M, Yang Y-X, Ren F-Z, Zeng Q-K, Robert Nout M (2007) A survey on the microbiological and chemical composition of buffalo milk in China. Food Control 18(6):742-746

He S, Ma Y, Wang J, Li Q, Yang X, Tang S, Li H (2011) Milk fat chemical composition of yak breeds in China. J Food Compos Anal 24(2):223-230

ISO-IDF (2001) Milk and milk products-Extraction methods for lipids and liposoluble compounds. International Standard ISO 14156-IDF, 172: 2001. International Dairy Federation, Brussels, Belgium

ISO-IDF (2002) Milk fat Preparation of fatty acid methyl esters. International Standard ISO 15884-IDF, 182: 2002. International Dairy Federation, Brussels, Belgium

ISO-IDF (2002) Determination of the milk fatty acid composition by gas-liquid chromatography. International Standard ISO 15885-IDF 184: 2002. International Dairy Federation, Brussels, Belgium

Kris-Etherton PM, Pearson TA, Wan Y, Hargrove RL, Moriarty K, Fishell V, Etherton TD (1999) Highmonounsaturated fatty acid diets lower both plasma cholesterol and triacylglycerol concentrations. Am J Clin Nutr 70(6):1009-1015

Medhammar E, Wijesinha-Bettoni R, Stadlmayr B, Nilsson E, Charrondiere UR, Burlingame B (2012) Composition of milk from minor dairy animals and buffalo breeds: a biodiversity perspective. J Sci Food Agr 92(3):445-474. doi:10.1002/Jsfa.4690

Mensink RP, Zock PL, Kester AD, Katan MB (2003) Effects of dietary fatty acids and carbohydrates on the ratio of serum total to HDL cholesterol and on serum lipids and apolipoproteins: a meta-analysis of 60 controlled trials. Am J Clin Nutr 77(5):1146-1155

Ramamurthy M, Narayanan K (1971) Fatty acid compositions of buffalo and cow milk fats by gas-liquid chromatography (GLC). Milchwissenschaft 26(11):693-697

Sheng Q, Li J, Alam MS, Fang X, Guo M (2008) Gross composition and nutrient profiles of Chinese yak (Maiwa) milk. Int J Food Sci Technol 43(3):568-572

Sun Q, Liu L, Zhang S-W, Liang X, Lv J-P (2012) Determination of calcium in milk by microwave digestion and flame atomic spectrometry. J Food Sci 33(14):162-165 (in Chinese)

Taguchi S, Ito-Oka E, Masuyama K, Kasahara I, Goto K (1985) Application of organic solvent-soluble membrane filters in the preconcentration and determination of trace elements: spectrophotometric determination of phosphorus as phosphomolybdenum blue. Talanta 32(5):391-394 
Talpur FN, Memon NN, Bhanger M (2007) Comparison of fatty acid and cholesterol content of Pakistani water buffalo breeds. Pak J Anal Environ Chem 8(1-2):15-20

Thac N (1979) Results of studies on F1 crossbreed of Murrah and Vietnamese local buffaloes. proceedings (Vietnamese) Results of research on Science and Technology (1969-1979) Agricultural Publish House Hanoi:154-163

Zeng Q-K, Yang B-Z, Liang K, Zhu G-Y, Nong H-R (2007) Study on physical and chemical properties of buffalo milk from different breeds and generations. China Dairy Ind 35(5):13-15 (in Chinese)

Zhang H, Yao J, Zhao D, Liu H, Li J, Guo M (2005) Changes in chemical composition of Alxa Bactrian camel milk during lactation. J Dairy Sci 88(10):3402-3410 